\title{
Superficial sediments and their relation to polychaete families in a subtropical embayment, Mexico
}

\author{
Nuria Méndez ${ }^{1}$ and María Green Ruiz ${ }^{1}$ \\ 1 Estación Mazatlán. ICMyL, UNAM Apdo. Posta1 811. Mazatlán 82000, Sinaloa, México. Fax: (69)82-61-33. e-mail: \\ nuri@ola.icmyl.unam.mx; mgreen@ola.icmyl.unam.mx
}

Received 31-VII-1997. 'Corrected 19-II-1998. Accepted 2-III-1998.

\begin{abstract}
The soft bottoms in front of Mazatlan Bay and "Isla de la Piedra" Peninsula were studied to produce maps (depth, grain size and organic matter content in sediments). Sixty samples were obtained with a $30 \times 30$ van Veen grab (4-21 m depth) and polychaetes were extracted from 21 subsamples. Grain size ranged from -1.05 phi (gravel) to 3.81 phi (very fine sand), with fine sand predominating. Organic matter content in sediment was $0.91-3.06 \%$ (most values $=1-2 \%$ ). Thirty polychaete families (905 individuals $/ \mathrm{m}^{2}$ in mean) were found, and Cirratulidae, Spionidae, Onuphidae, and Pilargiidae were dominant. Pearson's correlation of grain size, organic matter and depth proved significant $(p<0.01 ; p<0.02)$, confirming the observed relationships of distribution patterns in the area. A Principal Component Analysis showed the association of several families to depth (Factor 1), to grain size (Factor 2), and to organic matter (Factor 3). Nevertheless, the distribution of polychaete families in the area may be governed by the combination of the three abiotic variables. Results indicated that abiotic and biotic variables have not changed considerably since 1980 .
\end{abstract}

Key words: Sediments, grain size, organic matter, polychaetes, Gulf of California, Western Mexico.

The benthic fauna inhabiting soft bottoms presents a strong relationship with the size and texture of sediments. Several authors (Wieser 1959, Fresi et al. 1983, Junoy and Viéitez 1989) have demonstrated that the type of sediment plays an important role in the distribution of benthic fauna. Additionally, organic matter is an important parameter, since it represents the major food source of many detritivores (Rodríguez 1972). Many organisms may modify the texture of sediments during movement and feeding (Rhoads 1974). According to Gambi and Giangrande (1985a), the feeding guilds of many polychaetes inhabiting soft bottoms are strongly related to environmental features such as granulometry and organic content in sediments. Each polychaete family includes several feeding guilds (Fauchald and Jumars, 1979); nevertheless, such relationship can be assessed taking into account the family level, which is applicable to other faunistic groups. This strong relationship places sediment as a major component in any faunistic study.

Few studies on sediments have been undertaken in the Mazatlan Bay. In 1979-80, a multidisciplinary group from the Instituto de Ciencias del Mar y Limnología, UNAM, analysed sediments obtained in the depth range of $6-25 \mathrm{~m}$. The results, however, were never published. Orozco-Romo (1980) studied 
sediments in 68 collection sites chosen at random. He also produced a bathymetric map to a depth of $30 \mathrm{~m}$. Later, López-Avilés (1986) studied sediments from the continental slope off the coast of Sinaloa, including Mazatlan Bay. Unfortunately, recent data concerning grain size of sediments, organic matter content and bathymetry do not exit for shallow zones in the bay. Taking into account that such parameters are the basis of several sedimentological as well as benthic macrofaunal studies, a description of the whole area by means of cartographic maps representing their spatial distribution becomes necessary.

Only a few polychaete studies have been carried out in shallow bottoms inside the Mazatlan Bay. Rioja revised material collected between 1941 and 1962, but no data of depth have been reported in the majority of cases (see Salazar-Vallejo 1989). Chan-León (1983) analysed the families of polychaetes associated with rocky bottoms in the intertidal zone of the bay. The most recent studies concerning the polychaete fauna inhabiting shallow soft bottoms of Mazatlan Bay correspond to SolísWeiss (1983) and Arias-González (1984), who revised material collected at depths between 3.5 and $33 \mathrm{~m}$. The latter related the most frequent species with sediments grain size and concluded that this parameter may affect, among others, the polychaete distribution.

Because of the scarcity of studies related to the nature of soft bottoms in front of Mazatlan, the purpose of this study is to characterize the zone by means of depth and the spatial distribution of sediments according to their grain size and organic matter content. Moreover, the distribution of the polychaete families related to such characterization is analyzed.

\section{MATERIAL AND METHODS}

The city of Mazatlan is located in the Southeastern Gulf of California, on the Pacific coast of Mexico. Mazatlan Bay is a semienclosed embayment located between $23^{\circ} 10^{\prime}$ and $23^{\circ} 16^{\prime} \mathrm{N}$ and $106^{\circ} 25^{\prime}$ and $106^{\circ} 29^{\prime}$ $\mathrm{W}$, and includes a coastline of about $17 \mathrm{Km}$. It has an area of about $35 \mathrm{~km}^{2}$ along the continental platform. The northern limit of the bay is Pajaros Island and its most southerly point is Creston Hill, which forms a peninsula with the Neveria and the Vigia Hills. The "Isla de la Piedra" Peninsula, about $16 \mathrm{Km}$ long, is a sandy bar located to the south of Mazatlan Bay. It is bordered by the Urias Estuary which runs in a northeast direction, by the Presidio River in a southeast direction and by the open sea in a southwest direction (Montaño-Ley 1985). Sandy beaches predominate along the coast, except at Punta Camaron and in the southern portion of the bay, where rocky shore and cliffs are found. Some volcanic islands are located to the north (Pajaros, Venados, and Lobos Islands) and to the south (Hermanas Islands; Fig. 1). The spatial variation of the types of substrate is mainly related to the presence of currents and tides, as well as to the geomorphological features of each zone (Orozco-Romo 1980). The marine limit has been considered to be between 0 and $25 \mathrm{~m}$ depth (Arias-González 1984).

According to Orozco-Romo (1980), Mazatlan Bay comprises a typical marine ecosystem characterized by an homogeneous salinity (34 to $35 \mathrm{ppm}$ ) and by surface water temperature ranging from 20 to $30{ }^{\circ} \mathrm{C}$, depending upon the period of the year. Unfortunately, there are no detailed studies concerning marine currents. Some authors have observed seasonal changes in current direction depending mainly on wind direction and coastal physiography. Cabrera-Dueñas (1988) proposed a model describing how different situations of wind may affect currents in Maztlan Bay (e.g. predominant winds from the northwest produce currents in the same direction). Roden (1958) observed a predominant current in a northwest direction during winter-spring and a southeast direction during summer-autumn. Studies performed by 


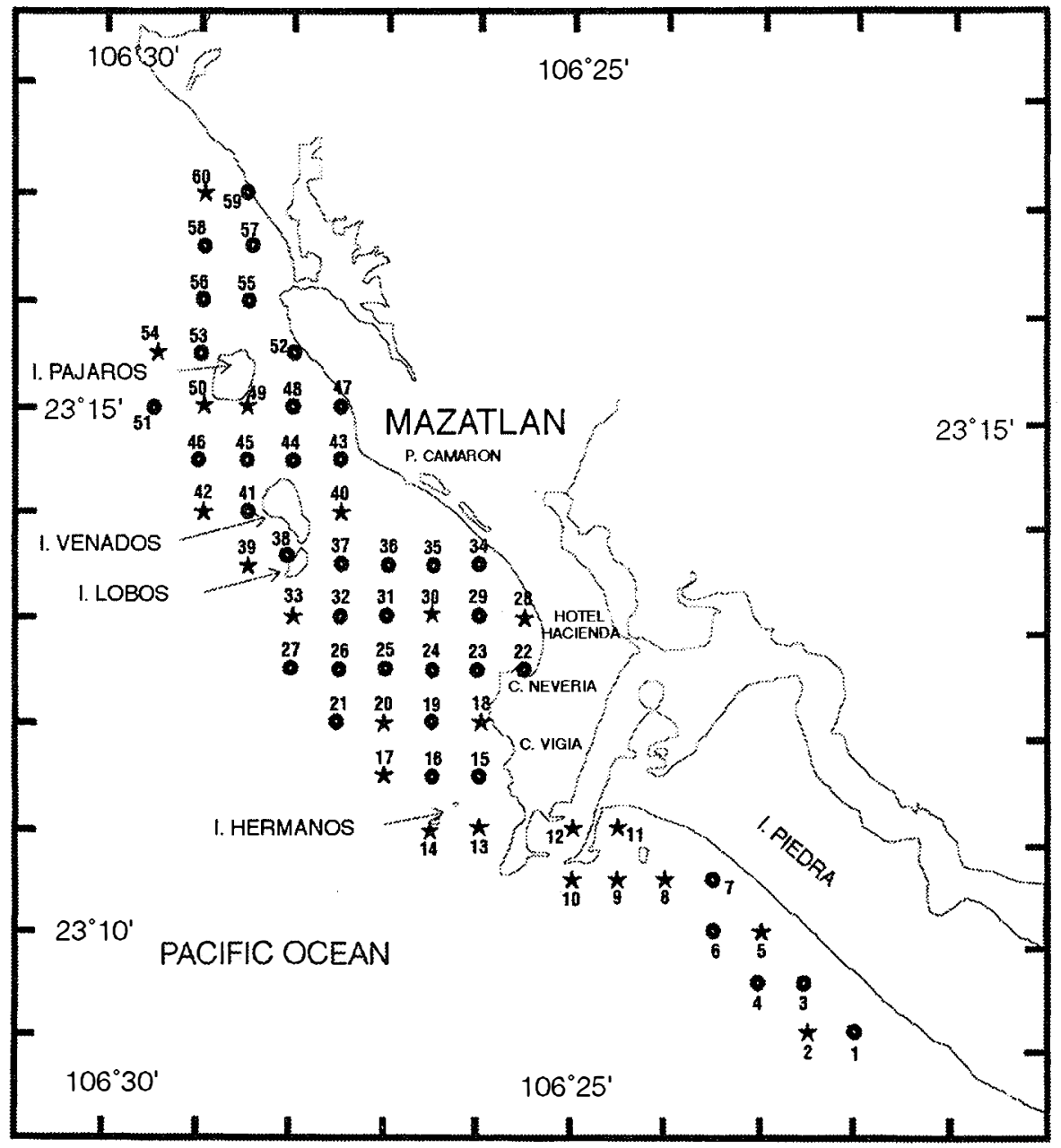

Fig. 1. Study area and the 60 collection sites (polychaete samples were obtained at the 21 sites market with an asterisk).

the Secretaría de Marina (Anonymous 1974) detected the presence of a main coastal current running parallel to the study area, with a westerly direction at "Isla de la Piedra" and changing its direction towards the northwest inside the bay.

The study area comprises an extensive area covering the entire Mazatlan Bay and extending about $6 \mathrm{~km}$ along the "Isla de la Piedra" Peninsula. Sediment samples were collected using a grid of 30 " of latitude by 30 ", of longitude. A total of 60 sampling sites were visited and an equal number of samples were obtained from a depth range of 4-21 m (Fig. 1). Sampling was performed from 3rd to 10th December, 1996.

Collection of samples was performed with a $30 \times 30 \mathrm{~cm}$ van Veen grab. To insure that only the superficial layer of sediments was collected, sub-samples for granulometric analyses and measurements of organic matter content were taken with a $2.5 \mathrm{~cm}$ diameter core introduced $3 \mathrm{~cm}$ inside the sediment contained in the grab. In each collection site, five sub- 
samples were taken in order to provide enough sediment for laboratory analyses. Depth was measured using a sounding line.

Grain size of sediments was obtained by wet sieving on a $2 \mathrm{~mm}(-1 \mathrm{phi})$ mesh width screen to sort gravel from sand and a 0.0625 $\mathrm{mm}$ (4 phi) mesh width screen to sort sand from mud (clay and silt), respectively. Analyses of mud were performed following the Pipette technique (Folk 1968). The mean size diameter of samples was calculated by the Moment statistic method (Krumbein and Pettijohn 1938). The granulometric Nomenclature of Wentworth (1922) was then applied. Organic matter was calculated by the loss of weight by ignition at $500^{\circ} \mathrm{C}$ to obtain percentages of organic carbon per sample (Dean 1974).

Samples of polychaetes were taken in 21 localities (of the 60 collection sites). These sites were chosen according to their spatial distribution, allowing a good representation of the whole study area. Once the five subsamples needed for sediments analyses were taken, the remaining sediment in the grab was sieved through a net with a mesh width of 0.5 $\mathrm{mm}$ and fixed with a $10 \%$ formaldehyde sea water solution on board. Specimens were later sorted and preserved in $70 \%$ ethyl alcohol. The specimens were identified to family level (Fauchald 1977) and counted. In order to allow further comparisons, a conversion factor of 12.47 was calculated to express density values as individuals per square meter (taking into account the substracted sub-samples for analyses).

Pearson's Correlation (Microsoft Excel for windows, version 7) was obtained for the abiotic variables (60 sites) and also for the abiotic versus biotic variables (21 sites). Moreover, a Principal Component Analysis (MINITAB for windows, release 10.2) was applied on data from the 21 sites containing polychaete information. The abiotic variables considered were depth, grain size of sediments, and organic matter content; the biotic variables were density (individuals $/ \mathrm{m} 2$ ) and number of families of polychaetes.

\section{RESULTS}

Depth ranged from 4 (site 11) to $21 \mathrm{~m}$ depth (site 14; Table 1). The spatial distribution presents a very clear pattern (Fig. 2a) and a general bathymetric gradient is observed, where depth increases with the distance from the coastline. In front of the Hacienda hotel, the slope increases faster forming a small depression.

Mean size diameter of sediments ranged from -1.05 phi (gravel; site 56) to 3.81 phi (very fine sand; site 33; Table 1). The spatial distribution of sediments showed that fine sand was well represented in almost the whole study area (Fig. 2b). A well defined patch containing very fine sand was observed. It begins in front of the Hacienda hotel and deviates to the northeast on the outer side of Lobos and Venados Islands. Only three sites contained gravelly bioclastic sediments composed mainly of fragments of mollusc and barnacle shells (site 10: $31.17 \%$; site $53: 30.0 \%$; site 56 : 61.94\%).

Organic matter contents in sediments were low [from $0.91 \%$ (site 1) to $3.06 \%$ (only in site 56)], and the majority of samples presented values ranging from 1 to $2 \%$ (Table 1 ).

A total mean density of 905 individuals $/ \mathrm{m}^{2}$ from 30 families of polychaetes were collected in the 21 collection sites (Table 2). According to mean density, Cirratulidae (239 individuals $/ \mathrm{m}^{2}$ ), Spionidae (199 individuals $/ \mathrm{m}^{2}$ ), Onuphidae (144 individuals $/ \mathrm{m}^{2}$ ), and Pilargiidae (56 individuals $/ \mathrm{m}^{2}$ ) were the most represented throughout the 21 sites. These four families were frequently found.

Pearson's Correlation values among abiotic variables from data of the 60 sites 
TABLE 1

Results of depth grain size of sediments and organic matter content

\begin{tabular}{|c|c|c|c|c|c|c|c|}
\hline Sites & Depth (m) & Sand $(\%)$ & Silt (\%) & Clay (\%) & Mean size (phi) & Gran. nomen. & Organic matte \\
\hline 1 & 13.0 & 74.32 & 15.36 & 10.32 & 3.12 & VFS & 1.38 \\
\hline 2 & 15.5 & 78.00 & 13.59 & 8.42 & 2.87 & FS & 1.60 \\
\hline 3 & 14.3 & 76.98 & 14.39 & 8.63 & 2.92 & FS & 1.85 \\
\hline 4 & 11.5 & 89.70 & 2.72 & 7.58 & 2.30 & FS & 1.02 \\
\hline 5 & 8.8 & 90.12 & 1.11 & 8.77 & 2.34 & FS & 1.28 \\
\hline 6 & 14.3 & 82.47 & 9.30 & 8.23 & 2.66 & FS & 1.63 \\
\hline 7 & 12.0 & 83.52 & 11.02 & 5.46 & 2.49 & FS & 1.47 \\
\hline 8 & 17.5 & 86.94 & 10.24 & 2.82 & 2.21 & FS & 2.11 \\
\hline 9 & 17.0 & 90.74 & 2.18 & 7.08 & 2.24 & FS & 1.37 \\
\hline 10 & 18.0 & 89.30 & 2.91 & 7.79 & 2.33 & FS & 2.69 \\
\hline 11 & 5.0 & 95.87 & 1.16 & 2.97 & 1.82 & MS & 0.94 \\
\hline 12 & 5.5 & 77.61 & 11.05 & 11.34 & 3.02 & VFS & 2.41 \\
\hline 13 & 14.5 & 84.35 & 3.25 & 12.40 & 2.69 & FS & 1.44 \\
\hline 14 & 21.0 & 87.81 & 8.73 & 3.56 & 2.21 & FS & 1.24 \\
\hline 15 & 13.0 & 93.10 & 2.16 & 4.74 & 2.02 & FS & 1.67 \\
\hline 16 & 16.5 & 91.89 & 4.01 & 4.10 & 2.05 & FS & 1.58 \\
\hline 17 & 18.5 & 86.98 & 7.85 & 5.17 & 2.30 & FS & 2.12 \\
\hline 18 & 10.5 & 91.26 & 4.46 & 4.28 & 2.09 & FS & 2.06 \\
\hline 19 & 15.0 & 86.34 & 10.24 & 3.42 & 2.27 & FS & 1.62 \\
\hline 20 & 16.0 & 91.41 & 5.75 & 2.84 & 2.01 & FS & 1.35 \\
\hline 21 & 19.0 & 80.59 & 12.05 & 7.36 & 2.70 & FS & 2.33 \\
\hline 22 & 6.5 & 90.82 & 5.43 & 3.74 & 2.08 & FS & 1.10 \\
\hline 23 & 12.0 & 90.73 & 6.02 & 3.25 & 2.06 & FS & 1.45 \\
\hline 24 & 13.8 & 76.53 & 18.66 & 4.81 & 2.77 & FS & 1.85 \\
\hline 25 & 14.0 & 60.42 & 35.39 & 4.19 & 3.47 & VFS & 2.28 \\
\hline 26 & 17.5 & 67.82 & 23.91 & 8.27 & 3.50 & VFS & 2.27 \\
\hline 27 & 15.0 & 80.39 & 12.87 & 6.74 & 2.69 & FS & 1.95 \\
\hline 28 & 6.5 & 94.48 & 2.29 & 3.23 & 1.89 & MS & 1.41 \\
\hline 29 & 8.3 & 91.21 & 2.80 & 6.00 & 2.16 & FS & 1.44 \\
\hline 30 & 12.0 & 66.56 & 25.31 & 8.13 & 3.37 & VFS & 2.10 \\
\hline 31 & 12.5 & 82.64 & 13.89 & 3.47 & 2.44 & FS & 1.72 \\
\hline 32 & 12.5 & 90.60 & 5.39 & 4.01 & 2.10 & $\dot{\mathrm{FS}}$ & 1.21 \\
\hline 33 & 16.6 & 58.59 & 31.15 & 10.16 & 3.81 & VFS & 2.27 \\
\hline 34 & 8.5 & 65.92 & 27.78 & 6.30 & 3.32 & VFS & 2.12 \\
\hline 35 & 11.0 & 88.24 & 7.34 & 4.42 & 2.23 & FS & 2.07 \\
\hline 36 & 11.0 & 89.84 & 5.31 & 4.85 & 2.18 & FS & 1.14 \\
\hline 37 & 11.0 & 87.60 & 8.32 & 4.08 & 2.24 & FS & 2.20 \\
\hline 38 & 14.5 & 89.23 & 4.68 & 6.09 & 2.26 & FS & 1.77 \\
\hline 39 & 18.5 & 62.23 & 27.44 & 10.33 & 3.66 & VFS & 2.37 \\
\hline 40 & 10.2 & 80.72 & 10.27 & 9.01 & 2.77 & FS & 2.39 \\
\hline 41 & 17.0 & 74.00 & 17.30 & 8.70 & 3.06 & VFS & 2.16 \\
\hline 42 & 17.0 & 88.26 & 6.21 & 5.23 & 2.25 & FS & 1.88 \\
\hline 43 & 6.0 & 90.98 & 4.74 & 4.28 & 2.10 & FS & 1.49 \\
\hline 44 & 9.8 & 90.07 & 4.89 & 5.04 & 2.17 & FS & 2.40 \\
\hline 45 & 13.5 & 71.27 & 23.91 & 4.82 & 3.01 & VFS & 2.06 \\
\hline 46 & 15.0 & 88.47 & 9.43 & 2.10 & 2.11 & FS & 1.82 \\
\hline 47 & 5.0 & 83.44 & 11.52 & 5.04 & 2.47 & FS & 1.32 \\
\hline 48 & 8.3 & 85.23 & 10.72 & 4.05 & 2.35 & FS & 2.07 \\
\hline 49 & 9.5 & 88.13 & 7.99 & 3.88 & 2.21 & FS & 2.12 \\
\hline
\end{tabular}

Cont... 
TABLE 1 CONT...

Results of depth grain size of sediments and organic matter content

$\begin{array}{lccccccc}\text { Sites } & \text { Depth }(\mathrm{m}) & \text { Sand }(\%) & \text { Silt }(\%) & \text { Clay }(\%) & \text { Mean size (phi) } & \text { Gran. nomen. } & \text { Organic matter ( } \\ 50 & 14.0 & 85.74 & 9.63 & 4.63 & 2.35 & \text { FS } & 1.86 \\ 51 & 18.5 & 75.22 & 19.24 & 5.34 & 2.84 & \text { FS } & 1.90 \\ 52 & 4.0 & 86.93 & 8.74 & 4.33 & 2.28 & \text { FS } & 1.67 \\ 53 & 13.0 & 92.35 & 1.63 & 6.02 & 2.12 & \text { FS } & 1.86 \\ 54 & 17.0 & 82.44 & 9.76 & 7.50 & 2.61 & \text { FS } & 1.87 \\ 55 & 11.0 & 93.33 & 3.04 & 3.63 & 1.96 & \text { MS } & 1.84 \\ 56 & 15.0 & 90.89 & 4.47 & 4.64 & 2.12 & \text { FS } & 3.06 \\ 57 & 10.0 & 91.72 & 3.45 & 4.83 & 2.09 & \text { FS } & 1.79 \\ 58 & 16.0 & 89.75 & 8.14 & 2.11 & 2.06 & \text { FS } & 2.64 \\ 59 & 7.5 & 92.74 & 1.17 & 6.09 & 2.10 & \text { FS } & 1.47 \\ 60 & 17.5 & 57.17 & 38.01 & 4.85 & 3.65 & \text { VFS } & 2.42\end{array}$

Granulometric nomenclature: VFS = very fine sand; FS = fine sand; $M S$ = medium sand; CS = coarse sand; $\mathrm{G}=$ gravel.
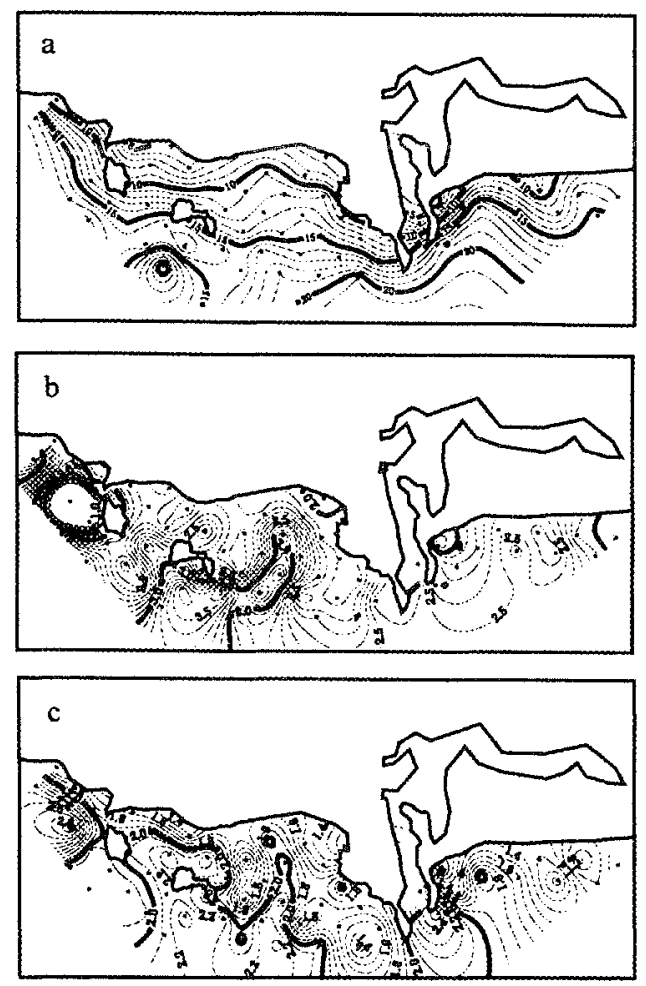

Fig. 2. Spatial distribution of the abiotic variables: a) depth (m); b) mean values (phi) of grain size of sediments; c) organic matter content $(\%)$ in sediments. showed that the highest positive correlation was found between grain size and organic matter $(\mathrm{r}=0.403 ; \mathrm{p}<0.01 ; \mathrm{n}=60)$. Finer sediments (size diameter increases with decreasing phi values) contain more amounts of organic matter and vice-versa. Depth was found to correlate significantly with organic matter $(\mathrm{r}=0.326 ; \mathrm{p}<0.01 ; \mathrm{n}=60)$ and grain size $(\mathrm{r}=0.308 ; \mathrm{p}<0.02 ; \mathrm{n}=60)$, Relative to abiotic variables (21 sites containing polychaete data), only the number of families was significantly correlated with grain size $(r=0.431 ; \mathrm{p}<0.05$; $n=21$ ). Correlation between the other pairs of biotic versus abiotic variables was found to be non significant.

A Principal Component Analysis was performed to gain greater insight into the functioning of the ecosystem. The three first factors extracted $22.4 \%, 17.5 \%$ and $11.0 \%$ of the variance, respectively (total variance extracted by the three factors $=50.8 \%$ ). Although the first factor shows better correlation with depth $(\mathrm{r}=0.154)$, the correlation with grain size $(\mathrm{r}=-$ $0.103)$ and organic matter $(\mathrm{r}=-0.089)$ demonstrate the same order of magnitude. The families weighting on this factor are Amphinomidae, Dorvilleidae, Lumbrineridae, 
TABLE 2

Density (individuals $/ \mathrm{m}^{2}$ ) of the families of polychaetes at the 21 sites and mean values (individuals $/ \mathrm{m}^{2}$ ) obtained for the entire system

Families

Sites

ORBINIIDAE

PARAONIDAE

2

8

$10 \quad 12$

$13 \quad 14 \quad 17$

$8 \quad 20 \quad 28$

$30 \quad 33$

39

$42 \quad 49$

$50 \quad 54 \quad 60 \quad$ Mean

SPIONIDAE

$\begin{array}{rrrrrrrrrrrrrrrrrrrrrr}0 & 62 & 12 & 0 & 0 & 12 & 0 & 0 & 0 & 12 & 0 & 0 & 25 & 12 & 50 & 25 & 0 & 0 & 0 & 12 & 12 & 11 \\ 0 & 100 & 0 & 0 & 0 & 25 & 0 & 0 & 0 & 0 & 0 & 0 & 0 & 0 & 0 & 25 & 0 & 0 & 0 & 12 & 37 & 10\end{array}$

MAGELONIDAE

$\begin{array}{llllllllllll}150 & 224 & 100 & 150 & 100 & 935 & 0 & 137 & 549 & 87 & 62\end{array}$

POECILOCHAETIDAE

$\begin{array}{rrrrrrrrr}37 & 224 & 100 & 150 & 100 & 935 & 0 & 137 & 549 \\ 37 & 25 & 37 & 0 & 0 & 0 & 0 & 0\end{array}$

CHAETOPTERIDAE

12
0

CAPITELLIDAE

MALDANIDAE

OPHELIIDAE

PHYLLODOCIDAE

ALCIOPIDAE

APHRODITIDAE

POLYNOIDAE

HESIONIDAE

PILARGIIDAE

SYLLIDAE

NEREIDAE

GLYCERIDAE

GONIADIDAE

NEPHTYIDAE

AMPHINOMIDAE

ONUPHIDAE

LUMBRINERIDAE

DORVILLEIDAE

FLABELLIGERIDAE

PECTINARIIDAE

AMPHARETIDAE

SABELLIDAE

$\begin{array}{rrrrrrrrrrr}0 & 0 & 0 & 0 & 0 & 0 & 0 & 0 & 0 & 0 & 0 \\ 87 & 287 & 0 & 574 & 12 & 748 & 711 & 948 & 0 & 898 & 37\end{array}$

$\begin{array}{llllllllll}25 & 12 & 0 & 0 & 0 & 636 & 0 & 62 & 0 & 25\end{array}$

$0 \begin{array}{rrr}0 & 0 & 0\end{array}$

SERPULIDAE

Total

$\begin{array}{rrrrrrrrrrr}37 & 50 & 25 & 0 & 0 & 0 & 37 & 511 & 0 & 50 & 239\end{array}$

$\begin{array}{rrrrrrrr}0 & 0 & 0 & 0 & 0 & 0 & 0 & 0\end{array}$

$\begin{array}{rrrr}0 & 12 & 0 & 25 \\ 37 & 0 & 0 & 0\end{array}$

$\begin{array}{rrrrrrrrrr}0 & 12 & 0 & 0 & 0 & 0 & 0 & 0 & 37 \\ 0 & 0 & 0 & 0 & 0 & 0 & 0 & 0 & 0\end{array}$

$\begin{array}{rrrrrrrr}0 & 0 & 0 & 0 & 0 & 0 & 0 & 0 \\ 25 & 12 & 0 & 25 & 0 & 12 & 0 & 0\end{array}$

$\begin{array}{lll}0 & 0 & 0 \\ 0 & 0 & 37\end{array}$

$\begin{array}{rrrrrrr}0 & 0 & 12 & 0 & 0 & 0 & 0\end{array}$

$\begin{array}{lll}262 & 25 & 25\end{array}$

$\begin{array}{llllll}0 & 0 & 0 & 0 & 0 & 0\end{array}$

$\begin{array}{rrrrrr}12 & 37 & 12 & 0 & 0 & 12\end{array}$

$\begin{array}{llllll}0 & 0 & 0 & 0 & 25 & 0\end{array}$

$\begin{array}{rrrrrr}75 & 12 & 62 & 50 & 0 & 12 \\ 0 & 0 & 0 & 0 & 0 & 37\end{array}$

$\begin{array}{rrrrrr}137 & 0 & 62 & 648 & 0 & 175 \\ 37 & 62 & 12 & 25 & 12 & 249\end{array}$

$\begin{array}{rrrrrr}25 & 0 & 0 & 25 & 0 & 87\end{array}$

12

$\begin{array}{rrrrrr}0 & 0 & 12 & 0 & 0 & 0\end{array}$

$\begin{array}{rrrrrr}12 & 0 & 25 & 37 & 0 & 287\end{array}$

$\begin{array}{rrrrrrrrrrr}0 & 0 & 12 & 0 & 0 & 0 & 0 & 0 & 0 & 0 & 25\end{array}$

$\begin{array}{lllllllllll}973 & 935 & 387 & 1683 & 237 & 3404 & 748 & 1147 & 624 & 1447 & 399\end{array}$

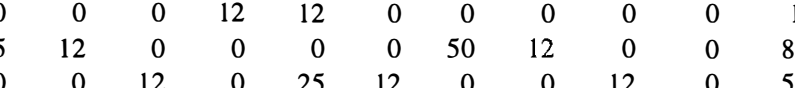

$\begin{array}{rrrrr}12 & 0 & 0 & 0 & 0\end{array}$

0

0
50

$0 \quad 0 \quad 50$

$\begin{array}{rrrr}0 & 25 & 0 \\ 0 & 0 & 0\end{array}$

$\begin{array}{rrrrrr}0 & 0 & 0 & 12 & 0 & 12 \\ 0 & 0 & 112 & 150 & 0 & 0\end{array}$

$\begin{array}{llllll}2 & 0 & 0 & 0 & 0 & 0 \\ 0 & 0 & 0 & 0 & 0 & 0\end{array}$

$\begin{array}{rrrrrr}37 & 37 & 0 & 12 & 25 & 12 \\ 0 & 0 & 0 & 0 & 0 & 0\end{array}$

$\begin{array}{rrr}0 & 37 & 12 \\ 0 & 0 & 0\end{array}$

$\begin{array}{rrr}0 & 287 & 75 \\ 0 & 12 & 25\end{array}$

$\begin{array}{llll}02 & 37 & 25 & 12\end{array}$

$\begin{array}{llllll}50 & 62 & 25 & 87 & 62 & 25\end{array}$

$\begin{array}{rrrrrr}599 & 100 & 75 & 112 & 87 & 175\end{array}$

00

$\begin{array}{ll}0 & 25\end{array}$

(1)

0 
Capitellidae, Nereidae, Sabellidae, Spionidae, and Flabelligeridae, which are associated with shallow bottoms (Fig. 3a).

The second factor is mainly reflected by grain size $(r=0.301)$, which decreases as positive values of the factor increase (Fig. 3a).
The families more represented in finer sediments were Polynoidae, Pilargiidae, Nephtyidae, Goniadidae, Chaetopteridae, Ampharetidae, Magelonidae and Maldanidae. On the other hand, Cirratulidae, Glyceridae, Syllidae, and Opheliidae prove to be associated with coarser sediments (Fig. 3a).
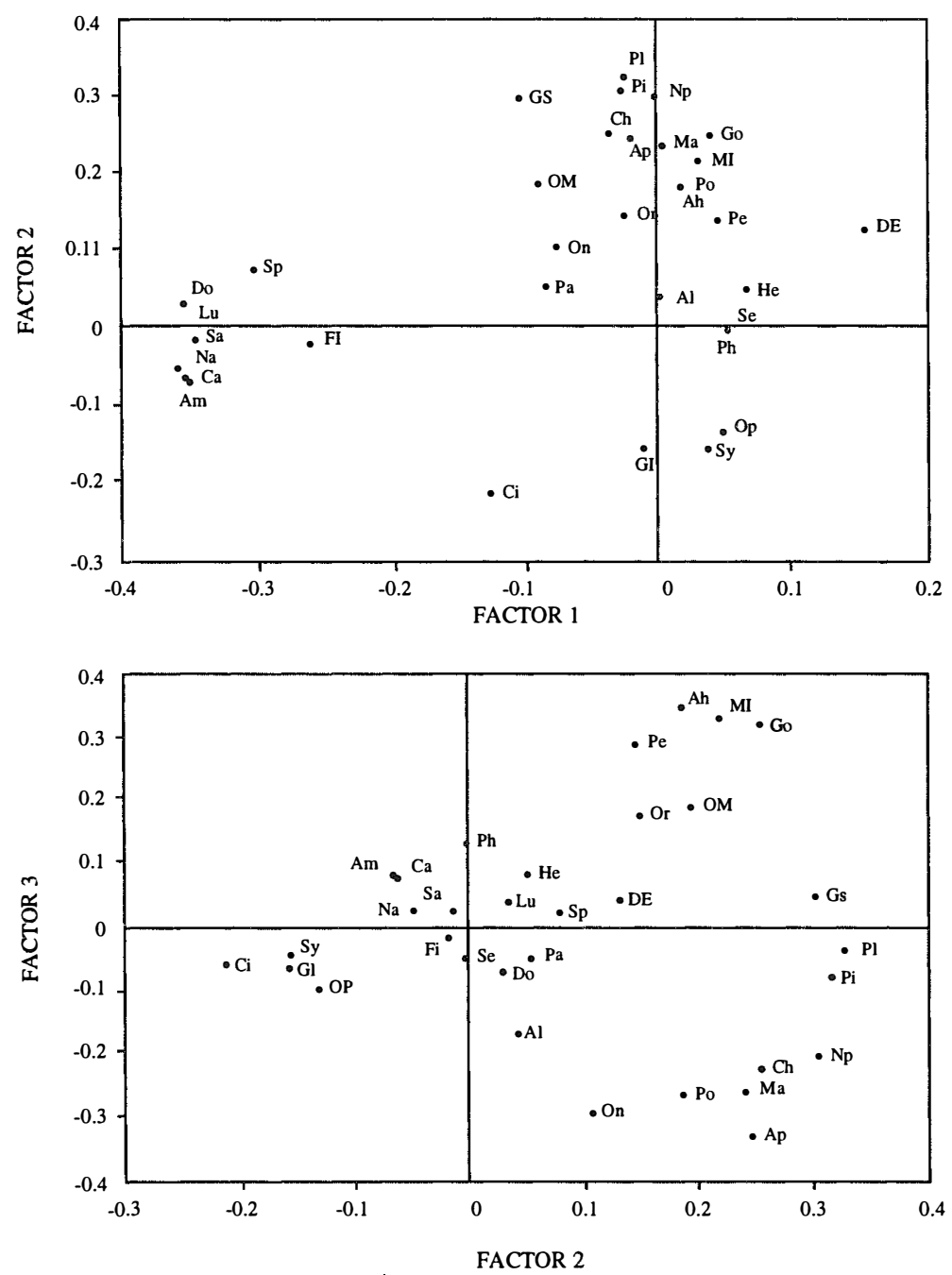

Fig. 3. Representation of the three abiotic variables and the 30 families of polychaees along the plane defined by factors 1 , 2, and 3 obtained in the Principal Component Analysis, using as co-ordinates their correlation with such factors: a) Factor 1 versus factor $2 ;$ b) factor 2 versus factor 3 ( $\mathrm{DE}=$ depth; $\mathrm{GS}=$ grain size; $\mathrm{OM}=$ organic matter; $\mathrm{Ah}=\mathrm{Aphroditidae} ; \mathrm{Al}=$ Alciopidae; $\mathrm{Am}=$ Amphinomidae; $\mathrm{Ap}=$ Ampharetidae; $\mathrm{Ca}=$ Capitellidae; $\mathrm{Ch}=$ chaetopteridae; $\mathrm{Ci}=\mathrm{Cirratulidae} ; \mathrm{Do}=$ Dorvilleidae; $\mathrm{Fl}=$ Flabelligeridae; $\mathrm{Gl}=$ Glyceridae; $\mathrm{Go}=$ Goniadidae; $\mathrm{He}=$ Hesionidae; $\mathrm{Lu}=$ Lumbrineridae; $\mathrm{Ma}=$ Magelonidae; $\mathrm{Ml}=$ Maldanidae; $\mathrm{Ne}=$ Nereidae$; \mathrm{Np}=$ Nephtyidae$; \mathrm{On}=$ Onuphidae; $\mathrm{Op}=$ Opheliidae; Or= Orbiniidae; $\mathrm{Pa}=$ Paraonidae; $\mathrm{Pe}=$ Pecinariidae; $\mathrm{Ph}=$ Phyllodocidae; $\mathrm{Pi}=\mathrm{Pilargiidae} ; \mathrm{Pl}=$ Polynoidae; $\mathrm{Po}=$ Poecilochaetidae; $\mathrm{Sa}=\mathrm{Sabellidae}$; $\mathrm{Se}=$ Serpulidae; $\mathrm{Sp}=$ Spionidae; $\mathrm{Sy}=$ Syllidae). 
The third factor correlates only to organic matter ( $\mathrm{r}=0.192)$. The families Aphroditidae, Maldanidae, Goniadidae and Pectinariidae are shown to be associated to sediments containing the higher amounts of organic matter (Fig. 3b), especially those located in the enriched patch around the islands (Fig. 2c). Ampharetidae, Onuphidae, Poecilochaetidae, Magelonidae, Chaetopteridae, and Nephtyidae resulted associated with sediments containing low amounts of organic matter.

\section{DISCUSSION}

The very fine sand patch detected in front of the Hacienda hotel (Fig. 2b) is associated with the deepest area (Fig. 2a) which may function as a trap of finer sediments. The deviation to the northeast may also be produced by a predominant current in the same direction. A similar pattern was reported by Orozco-Romo during 1980, which suggests that depth and sediment distribution in the bay have not considerably changed with time. The three sites characterized by the presence of gravelly bioclastic sediments (sites 10,53 and 56) are located close to rocky bottoms subjected to vigorous agitation by waves which cause the accumulation of fragmented shells in neighbour zones.

In relation with organic matter content, according to Parker (1939) and Hily, (1983: p. 41), typical beach and normal sands can contain from 0.5 to $5 \%$ of organic matter, which agrees with results found here. Nevertheless, the spatial distribution of organic matter content (Fig. 2c) showed two zones containing higher values: 1 ) in front of the mouth of the Urias Estuary, a natural ecosystem enriched with mangrove detritus and organic matter, and polluted by shrimp farms and food industrial areas, and also by terrigenous inputs; 2 ) in the middle of the bay, where a similar pattern to that of grain size is observed. The enrichment of these sediments with high amounts of silt and clay (Table 1) may have been produced by previous domestic inputs. Indeed, during the seventies and eighties, some domestic sewers were functioning in the vicinities of the Hacienda hotel. Their recent elimination during the nineties could have diminish organic content in such sediments. Unfortunately, there are no previous studies of organic matter contents to compare with our results.

Faunistic results have indicated that the highest density ( 3404 individuals $/ \mathrm{m}^{2}$ ) was found in site 12, just inside the Urias Estuary mouth. This is a confluence zone where marine and brackishwater mixing process may allow for the presence of high faunal variety. The estuary provide larvae of typical estuarine species and also nutrients and detritus (produced by mangrove trees) available for food, which may increase the number of individuals and families. Comparisons were made with data obtained during 1979-80 in Mazatlan Bay by Arias-González (1984), who collected polychaetes in the same kind of substrate and depth range. Of the 30 families reported in this study, 21 were found in common. Arias-Gonzáles (1984) indicated that Onuphidae, Spionidae and Lumbrineridae were the three most represented families in the bay, which coincides with our results.

Relationship between biotic and abiotic variables: The high correlation between grain size and organic matter can be explained because fine sediments present a larger available surface for adhesion of organic particles. This correlation was also observed by Fresi et al. (1983), Junoy and Viéitez (1989) and Méndez et al. (In press). The correlation values found between such abiotic variables with depth is probably due to the higher energy near the coastline does not allow deposition of finer materials. Relative to biotic variables, the correlation between the number of families with grain size has been observed by several authors such as Rhoads (1974), Gray (1981), Fresi et al. (1983) and Méndez et al. (1986), among others. 
According to Jumars and Fauchald (1977), Fauchald and Jumars (1979) and Gambi and Giangrande's (1985b) classifications, most of the feeding strategies and mobility categories of polychaetes are very well represented in the group of families associated with the first factor of the Principal Component Analysis (Fig. 3a): herbivorous, carnivorous, surface deposit feeders, subsurface deposit feeders, omnivorous, filtering and motile, discretely motile, burrowing, and sessile. These eight families were found in site 12 , and most of them were found exclusively in this site, which is located in the mouth of the Urias Estuary (Fig. 1). This is a very special area where water renewal allows the interchange of nutrients, detritus and larvae, increasing the number of feeding and mobility categories of such families of polychaetes. This suggests that the presence of these families in site $12(5.5 \mathrm{~m}$ depth $)$ is controlled by the combination of the three abiotic variables and the water interchange and not only by depth.

The majority of the eight families weighing positively in the second factor (Fig. 3a) can be discretely motile or burrowers, and their mobility may be favoured in fine compact sand for the construction of burrows or galeries, as has been pointed out by Wieser (1959). For the contrary, Cirratulidae, Glyceridae, Syllidae, and Opheliidae may be motile, discretely motile and burrowers (Jumars and Fauchald 1977, Fauchald and Jumars 1979, Gambi and Giangrande 1985b) and specimens found here were small in size. It is probable that they can move inside the sediments through the interstitial spaces produced among coarse grains.

Except for Goniadidae, the other families associated with the third factor (Aphroditidae, Maldanidae, and Pectinariidae; Fig. 3b) can be detritivorous and burrowers (Jumars and Fauchald 1977, Fauchald and Jumars 1979, Gambi and Giangrande 1985b), and this supports their association with enriched sediments. On the contrary, Ampharetidae, Onuphidae, Poecilochaetidae, Magelonidae,
Chaetopteridae, and Nephtyidae demonstrate association with sediments containing low amounts of organic matter, and this is reflected by their different diet guilds (detritivores were not dominant; Gambi and Giangrande 1985b), which indicates that they do not depend on food accumulated in sediments for survival.

Although several associations were observed through the Principal Component Analysis, the zonation of families seems to be not dependent on any exclusive abiotic variable analyzed. For instance, Maldanidae and Goniadidae showed a stronger affinity for fine sediments (factor 2) and for high amounts of organic matter (factor 3 ), and this coincides with the results of Pearson's correlation. Nepthyidae, Magelonidae and Chaetopteridae showed association with fine sediments (factor 2) and with low contents of organic matter (factor 3), in disagreement with the correlation between grain size and organic matter. The establishment of a clear zonation pattern is complicated if only the family level is taken into account, since this group is cosmopolitan at such taxonomic level (Fauchald 1977). Moreover, differences found in depth, grain size and organic matter values are not high enough to determine with precision the distribution of polychaete families in the study area. Results presented here, however, offer some pointers to the knowledge of sediment features of the polychaetes habitat, thus establishing the basis for further studies in the same area.

Results indicate that the Mazatlan Bay area might not have evolved significantly in the last 17 years, and that pollution related to the increase of the city size has not have a major impact on sediments composition due to organic matter deposition.

\section{ACKNOWLEDGMENTS}

We are grateful to scientists from the Instituto de Ciencias de Mar y Limnología, 
Estación Mazatlán, UNAM for their collaboration. To Alberto Castro for his help during sampling, for the processing of grain size samples and for the elaboration of Figs. using the Surfer Program. Thanks are given to José Salgado and Manuel Ayón for their help during sampling. We also thank Germán Ramírez and Alfredo Galaviz for their advice in multivariate programs and for the generation of the study area map, respectively.

\section{RESUMEN}

Se realizó una caracterización de los fondos blandos de la bahía de Mazatlán y de la Península "Isla de la Piedra" a través de mapa de profundidad, tamaño de grano y materia orgánica en sedimentos. Se recolect ron 60 muestras entre 4 y $21 \mathrm{~m}$ de profundidad con una draga van Veen de $30 \times 30 \mathrm{~cm}$. De estas 60 muestras, se recolectó sedimento en 21 localidades para el estudio de las familias de poliquetos. El tamaño de grano de los sedimentos osciló entre 1.82 phi (arena mediana) y 3.81 phi (arena muy fina), dominando la arena fina. El contenido de materia orgánica varió entre 0.91 y $3.06 \%$, siendo los valores comprendidos entre 1 y $2 \%$, los más frecuentes. En total se recolectaron 30 familias de poliquetos $\left(905\right.$ individuos $/ \mathrm{m}^{2}$ en promedio), de las cuales Cirratulidae, Spionidae, Onuphidae y Pilargiidae resultaron dominantes. Los valores de correlación de Pearson entre el tamaño de grano, la materia orgánica y la profundidad resultaron significativos $(\mathrm{p}<0.01$; $\mathrm{p}<0.02$ ), lo que confirma las relaciones observadas en los patrones de distribución a lo largo del área de estudio. El análisis de componentes principales mostró la asociación de varias familias con la profundidad (factor 1), con el tamaño de grano (factor 2) y con la materia orgánica (factor 3). Sin embargo, se sugiere que la distribución de las familias de poliquetos en el área de estudio está gobernada por la combinación de las 3 variables abióticas. Los resultados obtenidos aquí indican que las variables abiótica y bióticas no han cambiado considerablemente desde 1980 .

\section{REFERENCES}

Anonymous. 1974. Estudio Geográfico de la Región de Mazatlán, Sinaloa. Secretaría de Marina, México, D.F. $353 \mathrm{p}$.

Arias-González, J.E. 1984. Diversidad, distribución y abundancia de Anélidos Poliquetos de la bahía de
Mazallán, Si aloa, durante un ciclo anual. Professional Thesis, Universidad Nacional Autónoma de México, México, D.F., México.

Cabrera-Dueñas, H. 1988. Modelación hidrodinámica numérica del puerto de Mazatlán y sus proximidades. Professional Thesis. Universid d de Colima, Colima, México.

Chan-León, A. 1983. Contribución al conocimiento de la abundancia de Anélidos Poliquetos, en la zona intermareal y áreas adyacentes en la bahía de Mazatlán, Sinaloa, México. Professional Thesis, Universidad Autónoma de Sin loa, Mazatlán, México.

Dean, W. E. 1974. Determination of carbo ate and organic matter in calcareous sediments and sedimentary rocks by loss of ignition: comparison with others methods. J. Sed. Petrol. 44: 242-248.

Fauchald, K. 1977. The Polychaete Worms. Definitions and Keys to the Orders, Families and Genera. Nat. Hist. Mus. Los Angeles Country, Sci. Ser. 28. 188 p.

Fauchald, K. \& P. A. Jumars. 1979. The diet of worms: a study of Polychaete feeding guilds. Oceanogr. Mar. Biol. Ann. Rev. 17: 193-284.

Folk, R. 1968. Petrology of Sedimentary Rocks Hemphills, Austin, Texas. 170 p.

Fresi, E. M., C. Gambi, S. Focardi, R. Bargagli, F. Baldi \& L. Falcia. 1983. Benthic community and Sediment Types: A Structural Analysis. Mar. Ecol. 4: 101-121.

Gambi, M. C. \& A. Giangrande. 1985a. Analisi della struttura trofica del popolamento dei Policheti nei fondi mobili di due aree del Mar Tirreno. Oebalia 11 (N. S): 215-222.

Gambi, M. C. \& A. Giangrande. 1985b. Caratterizzazione e distribuzione delle categorie trofiche dei Policheti nei fondi mobili del Golfo di Salerno. Oebalia 11 (N. S): $223-240$

Gray, J. S. 1981. The Ecology of Marine Sediments. An Introduction to the Structure and Function of Benthic Communities. Cambridge University, Cambridge. $185 \mathrm{p}$.

Hily, C. 1983. Modifications de la structure écologique d'un peuplement de Melinna palmata (Annélide-Polychète) soumis aux effluents urbains et industriels en Rade de Brest. Ann. Inst. Océanogr., Paris. 59: 37-56.

Jumars, P.A. \& K. Fauchald. 1977. Feeding and metabolism. Between-community contrasts in successful polychaete feeding strategies. p. 1-20. In B. C. Coull (ed.): Ecology of marine benthos. University of South Carolina, Columbia, South Carolina. 
Junoy, J. \& J. M. Vieitez. 1989. Cartografía de los sedimentos superficiales de la ría de Foz (Lugo). Thalassas 7: 9-19.

Krumbein, W. C. \& F. J. Pettijohn. 1938. Manual of Sedimentary Petrography. Appleton-Century, New York. 549 p.

López-Aviles, R. 1986. Morfología y sedimentos superficiales de la porción meridional de la plataforma continental de Sinaloa, México. Professional Thesis, Universidad Nacional Autónoma de México, México, D.F., México.

Méndez, N., V. Solís-Weiss \& A. Carranza-Edwards. 1986. La importancia de la granulometría en la distribución de organismos bentónicos. Estudio de playas del estado de Veracruz, México. An. Inst. Cienc. del Mar. y Limnol. Univ. Nal. Autón. México 13: 45-56.

Méndez, N, J. Flos \& J. Romero. 1998. Littoral softbottom polychaete communities in a pollution gradient in front of Barcelona (Western Mediterranean, Spain). Bull. Mar. Sci. (in press)

Montaño-Ley, Y. 1985. Estudio del transporte litoral de arenas en la Isla de la Piedra, Mazatlán, Sin., usando trazadores fluorescentes. An. Inst. Cienc. del Mar. y Limnol. Univ. Nal. Autón. México, 12: 15-32.

Orozco-Romo, M. L. 1980. Estudio del macrobentos de la Bahía de Mazatlán, Sinaloa (con referencia especial a peces, equinodermos, crustáceos y moluscos. En relación con temperatura, salinidad, profundidad y tipo de sustrato). Professional Thesis, Universidad Autónoma de Guadalajara, Guadalajara, México.

Parker, D. 1939. Recent Marine Sediments. The American Association of Petroleum Geologist. Tulsa, Oklahoma: 261-268.

Rhoads, C. D. 1974. Organism-sediment Relations on the Muddy Sea Floor. Oceanogr. Mar. Ann. Rev. 12: 263300.

Roden, G.I. 1958. Oceanographic and meteorological aspects of the Gulf of California. Pac. Sci. 12: 21-45

Rodríguez, G., 1972. Las comunidades bentónicas. P. 563600. In: Fundación La Salle de Ciencias Naturales. Ecología Marina. Dossat, Caracas.

Salazar-Vallejo, S. I. 1989. Enrique Rioja y su contribución al estudio de los poliquetos (Annelida: Polychaeta) en México. Brenesia 30: 39-65.

Solís-Weiss, V. 1983. Parandalia bennei (Pilargidae) and Spiophanes lowai (Spionidae), new species of polychaetous annelids from Mazatlan Bay, Pacific coast of Mexico. Proc. Biol. Soc. Wash. 96: 370-378.

Wentworth, G. K. 1922. A scale of grade and class terms for clastic sediments. J. Geol. 30: 377-392.

Wieser, W. 1959. The effect of grain size on the distribution of small invertebrates inhabiting the Beaches of Puget Sound. Limnol. Oceanogr. 4: 181-194. 